\title{
Analisis Pemilihan Supplier Gabah dengan Metode Analitycal Network Proces (ANP) (Studi kasus: Gudang Baru Bulog Gunung Gedangan, Mojokerto)
}

\author{
Marista Amyriki ${ }^{1}$, Muhammad Fuad Fauzul Mu'amar², Sri Hastuti ${ }^{3}$ \\ 1,2,3Teknologi Industri Pertanian, Universitas Trunojoyo Madura \\ ${ }^{1}$ Marista1903@gmail.com, 2Fuadfm@gmail.com
}

\begin{abstract}
ABSTRAK
Pemilihan pemasok merupakan suatu kegiatan yang sangat penting dalam sebuah industri. Pemilihan pemasok yang baik dan tepat dapat meningkatkan kinerja perusahaan. Tujuan penelitian ini adalah mendapatkan kriteria dan subkriteria yang menjadi dasar pemilihan pemasok gabah dan mendapatkan alternatif pemasok gabah di GBB Gunung Gedangan, Mojokerto. Penentuan alternatif terbaik pada pemilihan pemasok gabah menggunakan metode Analitycal Network Process (ANP). Analisis kriteria terpilih pada penelitian ini didapatkan kriteria kualitas, kriteria pengiriman, kriteria fleksibilitas, kriteria responsibilitas dan kriteria service. Hasil penelitian menunjukkan bahwa kriteria kualitas mendapatkan bobot paling tinggi sebesar 0,53355, kriteria service $(0,26417)$, kriteria pengiriman $(0,10358)$, kriteria responsibilitas $(0,06164)$ dan kriteria fleksibilitas $(0,03705)$. Hasil penelitian menunjukkan bahwa alternatif pemasok yang tepat untuk perusahaan adalah UD. Satriya Sugih Waras dengan nilai 0,59073, kemudian UD. Sari Alam $(0,28194)$ dan UD. Arto Moro $(0,12733)$.
\end{abstract}

Kata Kunci: Gabah, pemasok, kriteria, subkriteria alternatif, ANP 


\section{Tahap Pengumpulan Data}

Data yang dibutuhkan didapatkan melalui observasi langsung, melakukan wawancara dengan pakar mengenai pemilihan pemasok gabah dan dilakukan penyebaran kuesioner kepada pakar. Pakar yang digunakan sebanyak 3 orang yaitu GBB Gunung Gedangan, Mojokerto untuk mengetahui penilaian alternatif dari masing- masing kriteria dan subkriteria. Menurut Puspitasari, A dan Udisubakti, C. (2011) jumlah pakar dalam penelitiannya yaitu 3 orang yang telah ahli dalam bidang penelitian penulis.

\section{Analisis Data}

Metode Analitycal Network Process (ANP) digunakan untuk mendapatkan alternatif pemilihan pemasok yang tepat bagi GBB Gunung Gedangan, Mojokerto. Pengolahan data menggunakan metode ANP dengan bantuan software Super Decisions.

\section{Tahap Pembahasan dan Kesimpulan}

Tahapan ini merupakan tahapan pembahasan data yang telah diperoleh dan diolah kemudian dari hasil pembahasan dapat ditarik sebuah kesimpulan.

\section{HASIL DAN PEMBAHASAN \\ Deskripsi Pemasok}

Pemasok gabah merupakan mitra kerja yang dimiliki Gudang Baru Bulog
Gunung Gedangan, Mojokerto. Perusahaan memerlukan hubungan kerjasama yang baik dengan mitra kerja. Pemilihan mitra kerja yang efektif, dapat membantu pihak perusahaan dalam mencapai hasil produksi yang diinginkan. Daftar mitra kerja gabah di GBB Gunung Gedangan, Mojokerto disajikan pada tabel berikut:

\section{Metode Pemilihan Mitra kerja Perusahaan}

Metode yang digunakan dalam pemilihan supplier di GBB Gunung Gedangan Mojokerto adalah sistem kontrak. Sistem kontrak merupakan suatu perjanjian antara GGB Gunung Gedangan Mojokerto dengan mitra kerja. Sistem kontak ini berlaku 1 bulan, apabila dalam waktu yang ditentukan mitra kerja tidak dapat memenuhi pasokan bahan baku sesuai jumlah yang tertera pada kontrak perjanjian akan dikenakan sanksi administratif (punishment).

\section{Kriteria Dan Sub-Kriteria Dalam Pemilihan Supplier Gabah}

Pada penentuan kriteria dalam pemilihan mitra kerja gabah di GBB Gunung Gedangan Mojokerto menggunakan kriteria kualitas, biaya, pengiriman, fleksibilitas, responsibilitas (Jannah et al, 2009) dan Service (Kurniawati, et al. 2013). Hasil Kriteria dan subkriteria terpilih disajikan pada tabel berikut:

Tabel 2. Kriteria dan Subkriteria Dalam Pemilihan Pemasok Gabah

\begin{tabular}{ll}
\hline Kriteria & Sub criteria \\
\hline Kualitas & $\begin{array}{l}\text { Kadar air 14\% } \\
\text { Kadar Hampa } 3 \% \\
\text { Ketepatan jumlah pengiriman } \\
\text { Ketepatan waktu pengiriman }\end{array}$ \\
Fleksibilitas & $\begin{array}{l}\text { Kemampuan memenuhi jumlah pengiriman } \\
\text { Kemampuan memenuhi dalam jangka waktu }\end{array}$ \\
Responsibilitas & $\begin{array}{l}\text { Kemampuan merespon masalah } \\
\text { Kemampuan merespon permintaan } \\
\text { Kervice }\end{array}$ \\
$\begin{array}{l}\text { Kemudahan komunikasi Pemberian } \\
\text { jaminan }\end{array}$
\end{tabular}


Tabel 3.Skala Penilaian Perbandingan Berpasangan

\begin{tabular}{ll}
\hline Skala & Definisi \\
\hline 1 & EleA dan B sama penting \\
3 & A sedikit lebih penting daripada B \\
5 & A lebih penting daripada B \\
7 & A sangat jelas lebih penting daripada B \\
9 & A mutlak lebih penting dari B \\
$2,4,6,8$ & Skala menengah (diantara dua kepentingan yang berdekatan) \\
\hline
\end{tabular}

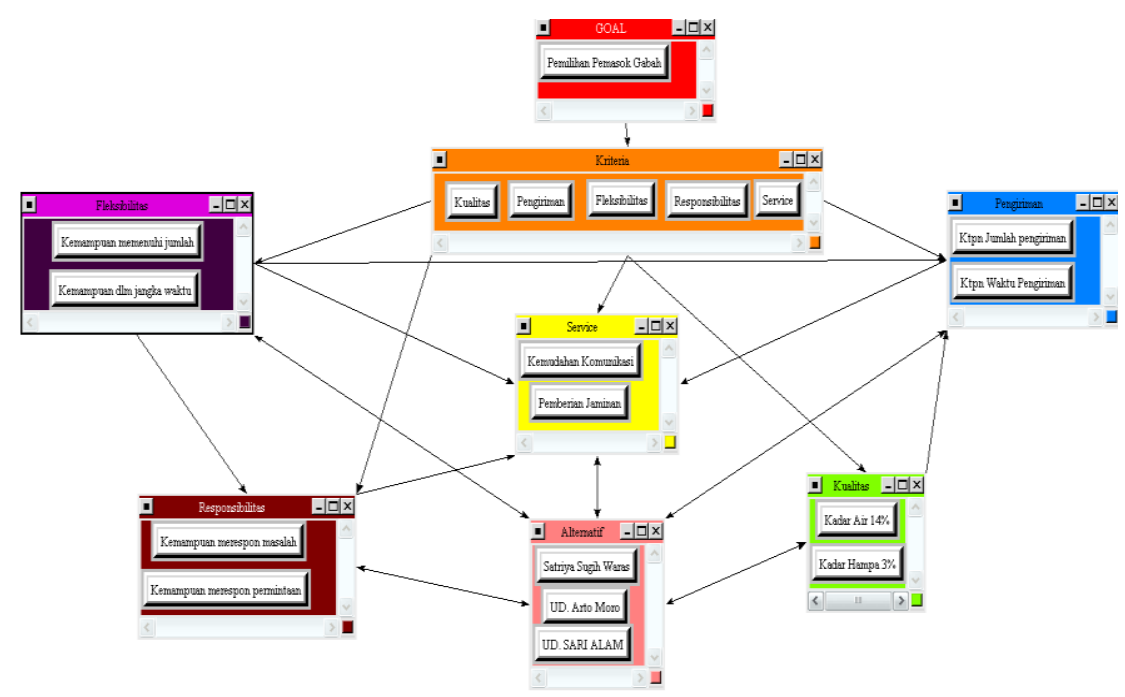

Gambar 1. Struktur Jaringan ANP Pemilihan Pemasok Gabah

Hasil Bobot Prioritas Penentuan Alternatif Pemilihan Pemasok Gabah Pada penentuan alternatif pemilihan pemasok gabah terbaik dilakukan dengan melakukan penilaian perbandingan berpasangan (parwaise comparison) antar kriteria, antar subkriteria dan antar alternatif berdasarkan subkriteria. Skala penilaian berdasarkan penelitian Lee, MC (2010) dapat dilihat pada tabel 3 di bawah ini:

\section{Pemodelan Network (Jaringan) ANP}

Network ANP didapatkan dari hasil kuesioner mengenai keterkaitan antar cluster yang terdiri dari satu cluster kriteria, lima cluster subkriteria dan satu cluster alternatif diolah dengan bantuan Software Super Decisions. Struktur jaringan ANP dapat dilihat pada Gambar 1.

\section{Analisis Pembobotan Kriteria}

Pembobotan kriteria didapatkan dengan melakukan perbandingan berpasangan antara kriteria satu dan lainnya, sehingga akan didapatkan bobot pada masing- masing kriteria dengan perbandingan berpasangan antar kriteria berdasarkan tingkat kepentingan antar kriteria tersebut. Data diperoleh dari kuesioner berpasangan yang telah diisi oleh pakar. Data yang telah diperoleh, kemudian diolah dengan metode ANP menggunakan bantuan program Software Super Decisions.

Hasil pengolahan data didapatkan bahwa bobot kriteria secara berurutan kualitas $(0,53355)$, service $(0,26417)$, pengiriman $(0,10358)$, responsibilitas $(0,06164)$, dan 
fleksibilitas $\quad(0,03705)$ Kualitas memiliki prioritas paling tertinggi, karena kualitas merupakan kriteria yang sangat penting dalam pemilihan mitra kerja. Kualitas gabah sangat mempengaruhi beras yang akan dihasilkan oleh GBB Gunung Gedangan, Mojokerto.

\section{Analisis Pembobotan Sub- kriteria}

\section{a. Kriteria Kualitas}

Pada kriteria kualitas terdiri 2 subkriteria yaitu kadar air 14\% dan kadar hampa $3 \%$. Diperoleh hasil pembobotan kadar air $14 \%$ $(0,66667)$ dan kadar hampa $3 \%$ $(0,33333)$. Kadar air lebih penting karena kadar air berpengaruh terhadap daya simpan gabah. Tempat atau ruang yang digunakan untuk ruang penyimpanan harus memenuhi syarat seperti bersih, kering, tidak lembab. Dengan penyimpanan yang baik, kualitas dapat dipertahankan dan dapat mencegah adanya kerusakan yang diakibatkan oleh faktor eksternal ataupun faktor internal.

Menurut Y.T. Prasetiyo (2002) faktor eksternal meliputi kelembaban udara, temperatur, serangan hama, sedangkan faktor internal meliputi kadar air. Ketika kadar air tinggi melebihi $14 \%$, gabah akan mudah terserang hama, serangga dan mudah mengalami kerusakan. Purwono dan Heni (2009) menjelaskan bahwa gabah kering giling (GKG) yang aman disimpan dalam jangka waktu 6 bulan yaitu gabah yang berkadar air maksimum $14 \%$, bertujuan supaya gabah dapat disimpan lebih lama tanpa adanya penurunan mutu.

\section{b. Kriteria Pengiriman}

Pada kriteria pengiriman terdiri dari 2 sub-kriteria yaitu ketepatan jumlah pengiriman dan ketepatan waktu pengiriman. Hasil pembobotan kriteria pengiriman bahwa ketepatan jumlah pengiriman $(0,5)$ dan ketepatan waktu pengiriman $(0,5)$. Pembobotan kedua subkriteria sama pentingnya. Karena hal ini terkait pada kinerja mitra kerja yang diinginkan oleh perusahaan dalam kegiatan pemenuhan bahan baku baik jumlah maupun waktu, sebab kegiatan pengiriman ini dapat mempengaruhi kelancaran kegiatan produksi suatu perusahaan.Kedua subkriteria ini menjadi salah satu penilaian penting bagi perusahaan serta memperkuat kontrak kerjasama antar kedua belah pihak.

\section{c. Kriteria Fleksibilitas}

Pada kriteria fleksibilitas terdiri dari 2 sub-kriteria yaitu kemampuan memenuhi jumlah dan kemampuan memenuhi dalam jangka waktu. Hasil pembobotan, kemampuan memenuhi jumlah $(0,5)$ dan kemampuan memenuhi dalam jangka waktu $(0,5)$. Didapatkan kedua subkriteria sama pentingnya. Karena mitra kerja harus memiliki kriteria ini karena bagaimana mitra kerja mampu atau tidak dalam kegiatan pemenuhan bahan baku. Apabila salah satu komponen diabaikan maka mitra kerja akan dikenai sanksi administratif (punishment). Kedua subkriteria ini mengacu pada kontrak perjanjian yang di lakukan oleh pihak mitra kerja ke perusahaan.

\section{d. Kriteria Responsibilitas}

Kriteria responsibilitas terdiri 2 subkriteria yaitu kemampuan mitra kerja merespon masalah dan kemampuan mitra kerja merespon permintaan. Hasil pembobotan kamampuan mitra kerja merespon masalah $(0,5)$ dan kemampuan mitra kerja merespon permintaan $(0,5)$. 
Keduanya sama pentingnya, karena keduanya harus dimiliki oleh mitra kerja artinya bagaimana mitra kerja menanggapi suatu permasalahan yang akan dihadapi oleh perusahaan terkait dengan bahan baku dan mitra kerja juga harus melakukan tindakan ketika terjadi keluhan mengenai permintaan bahan baku. Maka tidak bisa salah satu komponen dihiraukan, karena kedua komponen ini saling berkaitan.

\section{e. Kriteria Service}

Kriteria service terdiri dari 2 subkriteria yaitu kemudahan komunikasi dan pemberian jaminan.

Hasil pembobotan pemberian jaminan $(0,83333)$ dan kemudahan komunikasi $(0,16667)$ bahwa pemberian jaminan lebih penting. Setiap mitra kerja yang akan membuka kontrak kerja harus memberikan jaminan kepada pihak perusahaan. Pemberian jaminan ini berupa uang kepada GBB Gunung Gedangan, Mojokerto yang bertujuan untuk mengikat mitra kerja agar jumlah gabah sesuai dengan kontrak perjanjian dan barang yang dikirim bisa tepat waktu.

\section{Analisis Pembobotan Prioritas Alternatif Dalam Pemilihan Mitra kerja}

a. Kadar Air $14 \%$

Hasil pembobotan alternatif yaitu UD. Satriya Sugih Waras $(0,66484)$, UD. Sari Alam $(0,24493)$ dan UD. Arto Moro $(0,09023)$. Pada subkriteria ini UD. Satriya Sugih Waras memperoleh hasil pembobotan alternatif tertinggi, karena kualitas gabah yang dihasilkan mempunyai kadar air kurang dari $14 \%$, sehingga kualitas gabah yang dihasilkan UD. Striya Sugih Waras sangat bagus.

\section{b. Kadar Hampa 3\%}

Hasil pembobotan alternatif yaitu UD. Satriya Sugih Waras $(0,63484)$, UD. Sari Alam $(0,28720)$ dan UD. Arto Moro $(0,07796)$. Didapatkan UD. Satriya Sugih Waras memperoleh hasil pembobotan tertinggi, karena pada kegiatan pengadaan bahan baku kualitas gabah yang dihasilkan mempunyai kadar hampa kurang dari 3\% sehingga kualitas gabah yang dihasilkan UD. Satriya Sugih Waras sangat bagus. Kadar hampa ini mempengaruhi berat gabah, karena apabila semakin banyak kadar hampa semakin banyak pula penyusutan.

\section{c. Ketepatan Jumlah Pengiriman}

Hasil pembobotan alternatif UD. Satriya Sugih Waras $(0,33333)$, UD. Sari Alam $(0,33333)$ dan UD. Arto Moro (0,33333). Ketiga alternatif memiliki bobot sama, karena pada subkriteria ketepatan jumlah pengiriman, ketiga alternatif selalu dapat memenuhi jumlah bahan baku. Apabila mitra kerja tidak dapat memenuhi jumlah bahan baku, mitra kerja akan dikenai sanksi berupa membayar denda keterlambatan yang sudah ditetapkan oleh perusahaan.

\section{d. Ketepatan Waktu Pengiriman}

Hasil pembobotan alternative yaitu UD. Satriya Sugih Waras $(0,72230)$, UD. UD. Sari Alam $(0,20499)$ Arto Moro $(0,07272)$. UD Satriya Sugih Waras mendapatkan bobot tertinggi karena pada kegiatan pengadaan bahan baku UD Satriya Sugih Waras dapat memenuhi bahan baku sebelum batas waktu yang ditentukan, sehingga hal ini sangat menguntungkan perusahaan untuk mendapatkan pasokan bahan baku yang cukup banyak. 


\section{e. Kemampuan Memenuhi}

Jumlah Hasil pembobotan alternatif yaitu UD. Satriya Sugih Waras $(0,33333)$, UD. Sari Alam $(0,33333)$ dan UD. Arto Moro (0,33333). Ketiganya memiliki bobot yang sama yaitu memiliki kemampuan yang sama dalam pemenuhan bahan baku dari segi jumlah, apabila mitra kerja tidak dapat memenuhi jumlah sesuai kontrak perjanjian, maka mitra kerja akan dikenai denda keterlambatan yang nantinya akan merugikan pihak mitra kerja itu sendiri.

\section{f. Kemampuan Memenuhi Dalam Jangka Waktu}

Hasil pembobotan alternatif yaitu UD. Satriya Sugih Waras $(0,64422)$, UD. Sari Alam $(0,27056)$ dan UD. Arto Moro (0,08522). Didapatkan bahwa UD. Satriya Sugih Waras memperoleh hasil pembobotan alternatif tertinggi karena pada kegiatan pengadaan gabah mampu memenuhi barang sebelum batas waktu yang sudah ditentukan di kontrak perjanjian. Hal ini sangat menguntungkan perusahaan karena akan mudah mendapatkan pasokan bahan baku secara cepat dan dapat menambah stok di Gudang.

\section{g. Kemampuan Mitra Kerja Merespon Masalah}

Hasil pembobotan alternatif yaitu UD. Sari Alam (0,60456), UD. Arto Moro $(0,29064)$ dan UD. Satriya Sugih Waras $(0,10479)$. Pada subkriteria ini UD. Sari Alam memperoleh bobot tertinggi terkait kemampuan dalam merespon permasalahan yang terjadi di perusahaan terutama permasalahan yang terjadi terkait dengan pengadaan bahan baku.

Permasalahan yang terjadi ketika panen tiba yaitu ketersediaan gabah yang sedikit di Wilayah sekitar UD.
Sari Alam. Dalam kondisi seperti ini UD. Sari Alam bisa mendapatkan gabah yang cukup banyak serta cepat tanggap dengan cara mendapatkan gabah diluar daerah Jawa Timur.

\section{h. Kemampuan Mitra Kerja Merespon Permintaan}

Hasil pembobotan alternatif yaitu UD. Sari Alam $(0,68172)$, UD. Arto Moro $(0,23634)$ dan UD. Satriya Sugih Waras $(0,08193)$. Pada subkriteria ini UD. Sari Alam memperoleh bobot tertinggi dalam kemampuan dalam merespon permasalahan terkait dengan permintaan bahan baku. Untuk memenuhi permintaan, ketika panen padi di daerah sekitar UD. Sari Alam tidak memenuhi. UD. Sari Alam membeli padi hingga ke luar Jawa Timur untuk mendapatkan gabah yang diinginkan, sehingga UD. Sari Alam dapat memperoleh gabah yang cukup banyak untuk memenuhi kebutuhan bahan baku perusahaan. Hal ini akan sangat menguntungkan kedua belah pihak antara mitra kerja dan perusahaan.

\section{i. Kemudahan Komunikasi}

Hasil pembobotan alternatif yaitu UD. Satriya Sugih Waras $(0,72230)$, UD. Sari Alam $(0,20499)$ dan UD. Arto Moro (0,07272). Didapatkan bahwa UD. Satriya Sugih Waras memperoleh hasil pembobotan tertinggi dalam subkriteria kemudahan komunikasi, karena lebih mempunyai sifat kooperatif terhadap perusahaan.

\section{j. Pemberian Jaminan}

Pada hasil pembobotan alternatif yaitu UD. Sari Alam (0,68172), UD. Arto Moro $(0,23634)$ dan UD. Satriya Sugih Waras $(0,08193)$. UD Sari Alam mendapatkan bobot tertinggi, karena pada kontrak perjanjian 
besar kecilnya jaminan ditentukan oleh jumlah pengadaan. Semakin banyak jumlah pengadaan, maka jaminan yang diberikan mitra kerja kepada perusahaan semakin banyak pula. Jaminan ini bertujuan mengikat mitra kerja agar jumlah barang yang dikirim sesuai dengan kontrak perjanjian dan barang yang dikirim dapat dipenuhi tepat waktu.

\section{Analisis Hasil Pembobotan Alternatif Mitra kerja}

Pemilihan supplier gabah di GBB Gunung Gedangan, Mojokerto dilakukan menggunakan metode Analaitycal Network Process (ANP) dengan bantuan program software Super Decisions. Hasil pembobotan prioritas alternatif disajikan pada tabel 4.

Hasil pengolahan data penggunakan software Super Decisions. Menunjukkan bahwa Satriya Sugih Waras menjadi prioritas utama dalam pemilihan mitra kerja yaitu $(0,59073)$, prioritas kedua yaitu Sari Alam $(0,28194)$, prioritas terakhir adalah Arto Moro $(0,12733)$. Artinya mitra kerja Satriya Sugih Waras memiliki kinerja yang paling bagus, jika dibandingkan dengan mitra kerja Sari Alam dan Arto Moro. Penilaian ini mencakup 10 sub-kriteria yaitu

Tabel 4. Alternatif Pemilihan Pemasok Gabah

\begin{tabular}{lcc}
\hline Alternatif & Bobot & Prioritas \\
\hline UD.Satriya Sugih & 0,59073 & 1 \\
UD.Sari Alam & 0,28194 & 2 \\
UD.Arto Moro & 0,12733 & 3 \\
\hline
\end{tabular}

kadar air 14\%, kadar hampa 3\%, ketepatan jumlah pengiriman, ketepatan waktu pengiriman, kemampuan mitra kerja memenuhi jumlah, kemampuan mitra kerja memenuhi dalam jangka waktu, kemampuan mitra kerja merespon masalah, kemampuan mitra kerja merespon permintaan, kemudahan komunikasi dan pemberian jaminan.

\section{SIMPULAN DAN REKOMENDASI}

\section{Kesimpulan}

Kriteria-kriteria terpilih yang digunakan dalam pemilihan supplier gabah di GBB Gunung Gedangan, Mojokerto yaitu kualitas dengan bobot 0,53355 , service 0,26417 , pengiriman 0,10358 , responsibilitas 0,06164 dan fleksibilitas 0,03705 .

Hasil perhitungan penentuan alternatif terbaik dalam pemilihan supplier gabah di GBB Gunung Gedangan, Mojokerto dengan metode ANP (Analytical Network Process) didapatkan hasil UD. Satriya Sugih Waras mendapatkan nilai tertinggi yaitu 0,59073, UD. Sari Alam 0,28194 dan UD. Arto Moro 0,12733.

\section{Saran}

Penelitian selanjutnya perlu menambahkan beberapa kriteria dan subkriteria lain untuk menambah tingkat akurasi dalam pemilihan alternatif pemasok di Gudang Baru Bulog Gunung Gedangan, Mojokerto.

Perusahaan perlu meningkatkan jalinan kerjasama dengan mitra kerja untuk memperoleh pasokan gabah dari pemasok sehingga akan mendapatkan gabah yang memenuhi standar dan menghasilkan beras yang berkualitas. 



\section{DAFTAR PUSTAKA}

Bulog.

2014.

Sekilas

Perusahaan.(Online).http://www .bulog.co.id/sekilas.php.

Diakses tanggal 19 November 2014.

Fitriana, N. 2013. Analisis Kinerja Karyawan Berdasarkan Kompetensi Dengan Metode Analytic Network Process (ANP) Dan Rating Scale (Studi Kasus Di PT. Erindo Mandiri Pasuruan). [Skripsi]. Malang: Universitas Brawijaya Malang.

Hidayati, J. 2012. Penerapan Analitycal Network Process (ANP) pada Sistem Pengukuran Kerja di Kebun Sidamanik Pematang Siantar. Jurnal Teknik Industri, 7(1):51-60.

Jannah, M., Fakhry, M. \& Rakhmawati. 2013. Pengambilan Keputusan Untuk Pemilihan Supplier Bahan Baku Dengan Pendekatan Analytic Hierarchy Process di PR Pahala Kencana. Jurnal Agrointek, 5(2):88-97.

Kurniawati, D., Yuliando, H. \& Kuncoro, H.W. 2013. Kriteria Pemilihan Pemasok menggunakan ANP. Jurnal Teknik Industri, 15(1):2532.

Lee, M-C. 2010. The Analytic Hierarchy and The Network Process in Multicriteria Decision Making: Performance Evaluation and Selecting Key Performance Indicators Based on ANP Model. Dalam M.Crisan (Ed). Convergence and Hybrid Information Technologie (hlm. 125-147). Vukovar, Croatia: Intech.
Prasetiyo, Y.T. 2002. Padi Sawah TOT (Tanpa Olah Tanah). Yogyakarta: Kanisius.

Purwono dan Heni, P. 2009. Budidaya 8 Jenis Tanaman Pangan Unggul. Jakarta: Penebar Swadaya

Puspitasari, A dan Udisubakti, C. 2011. Aplikasi Model Zero- One Programming, DEMATEI \& ANP Untuk Optimasi Pemilihan Strategi Pemasaran. [Skripsi] Jurusan Teknik Industri. Institut Teknologi Sepuluh November Surabaya.

Wibisono, Y.Y dan Kristi. 2013. Pemilihan Pemasok Dengan Metode Analytic Network Process (Studi Kasus Di PT. Al). Makalah disajikan dalam Seminar Nasional IENACO, Jurusan Teknik Industri, Bandung.

Yulianti, M. 2013. Penerapan Metode Analitycal Network Process (ANP) dan Technique For Order Preference By Similarity To Idel Solution (TOPSIS) dalam Pemilihan Supplier. [Skripsi]. Jakarta. Universitas Pendidikan Indonesia.

Yoserizal,Y dan Moses. 2012. Integrasi Metode Dematel (Decision Making Trial And Evaluation Laboratory) Dan ANP (Analytic Network Process) Dalam Evaluasi Kinerja Supplier Di PT. XYZ. Makalah disajikan dalam Prosiding Seminar Nasional Manajemen Teknologi XV. Program Studi MMT-ITS, Surabaya, 4 Februari. 